Історико-політичні проблеми сучасного світу: Збірник наукових статей. - Чернівці: Чернівецький національний університет, 2020. - T. 42. - C. 77-88

DOI: $10.31861 / \mathrm{mhpi} 2020.42 .77-88$

УДК $341.76(477+536.8)$
Modern Historical and Political Issues: Journal in Historical \& Political Sciences. - Chernivtsi: Chernivtsi National University, 2020. - Volume. 42. - pp. 77-88 DOI: $10.31861 / \mathrm{mhpi} 2020.42 .77-88$

\section{(C) Ольга Сегеда ${ }^{1}$ \\ (C) Володимир Смолянюк ${ }^{2}$}

\title{
Сучасні процеси цифровізації в дипломатичній службі України та Кувейту
}

У статті розглянуто сучасну практику здійснення цифрової дипломатії (ЦД) на прикладі міністерств закордонних справ України та Кувейту. На основі наукової літератури 2019-2020 pp. стосовно досліджуваної проблематики проаналізовано ключові сфери цифровізації в дипломатичних службах згаданих держав, зокрема запровадження консульських онлайн-послуг, здійснення інформаційної роботи та публічної дипломатії, цифровізація освітньої підготовки дипломатів, застосування цифрових інструментів у щоденній дипломатичній практиці тощо. 3'ясовано основні фактори активізації застосування ЦД зовнішньополітичними відомствами України та Кувейту. Проаналізовано вплив високих технологій на трансформацію традиційної дипломатії, досліджено цілі, інструментарій та виклики ЦД України та Кувейту, укладено порівняльну таблицю для унаочнення спільних і відмінних рис у здійсненні цифрової дипломатії обох країн.

Ключові слова: цифрова дипломатія, цифровізація дипломатичної практики, Україна, Кувейт, інструментарій цифрової дипломатії.

\section{Modern Processes of Digitalization in Diplomatic Service of Ukraine and Kuwait}

The paper provides an overview of the current digital diplomacy (DD) practices being implemented by the Ministries of Foreign Affairs (MFA) of Ukraine and Kuwait. Given the fact that digital diplomacy is becoming an integral part of the foreign policy in numerous countries, it appears reasonable to analyze the latest experience of Ukraine and Kuwait which represent a fast implementation of digital instruments in their diplomatic practices. Both states are considered as long-time partners which enjoy a fruitful experience of mutual cooperation and have certain peculiarities in the use of digital diplomacy. At the same time, high technologies transform the traditional diplomacy, dramatically increasing the digital impact on the practice and priorities of international relations. Such challenges as digital diplomatic management, targeting of widening key audiences and increasing transparency of diplomatic actions have already become a new reality for modern diplomats.

Therefore, the purpose of this paper is to clarify the goals, tool-kit and challenges of digital diplomacy of Ukraine and Kuwait. The paper also presents a comparative analysis of existing positive practices of Ukraine and Kuwait in digital diplomacy. This research made it possible to trace the key areas of the digitalization processes in the diplomatic services of Ukraine and Kuwait including consular online services, digitalization of diplomats' training, the use of digital instruments in the routine diplomatic procedures etc. The author elaborated a comparative table outlining the similarities and differences of digital diplomacy of the mentioned countries. The study confirms that digital diplomacy can be helpful in a range of issues, from internal communication between government bodies to security challenges (e.g. countering information threats and disinformation in the online network). Thus, the coordinated and comprehensive digitalization of diplomatic practice is no longer a subject of discussions on feasibility but a priority on the diplomatic agendas.

Keywords: digital diplomacy, digitalization of diplomatic practices, Ukraine, Kuwait, tool-kit of digital diplomacy.

\footnotetext{
1 Магістр східної філології, третій секретар Посольства України в Державі Кувейт, Україна. Е-mail: olha.seheda@protonmail.com; https://orcid.org/0000-0001-5155-9515.

2 Доктор політичних наук, професор, завідувач кафедри політичних технологій Київського національного економічного університету імені Вадима Гетьмана, Україна. E-mail: svf-nb@ukr.net; https://orcid.org/00000002-4222-813X.
} 
Постановка проблеми. Процеси цифровізації дедалі глибше проникають у всі сфери діяльності людини. Не стала винятком і дипломатична служба, оскільки повсякденна робота дипломата не могла не зазнати трансформацій унаслідок розвитку інформаційно-комунікаційних технологій (ІКТ). Отже, звертаючись до питання цифровізації сфери міжнародних відносин, можна констатувати, що дедалі активніше запровадження ІКТ в дипломатичну практику вимагає переосмислення майже кожного аспекту дипломатичної діяльності у віртуальному просторі: від цифрового етикету та правил комунікації в мережі до кібербезпеки та попередження інформаційних загроз.

Аналіз останніх досліджень із окресленої проблеми. Останніми роками до проблеми цифрової трансформації дипломатії зверталося чимало науковців, зокрема I. Манор i Н. Сефьяні, які аналізують різні боки цифровізації дипломатії: від «твіпломатії» до глибшого розуміння «цифровізації публічної дипломатії». Дж. Паммент, Бр. Хокінг, Ян Меліссен досліджують питання цифрової трансформації публічної дипломатії та іiї виклики (медіатизацію, розширення кола цільової авдиторії, підвищення відкритості роботи дипломатів, менеджмент дипломатичної діяльності тощо).

Українськомовна база наукових досліджень 2019-2020 pp., присвячених процесам цифровізації дипломатичної практики України, налічує багато робіт, зокрема авторства Н. Піпченко, Є. Макаренко, М. Рижкова, О. Русової, В. Гуленко, Я. Матчука, О. Григор'євої, О. Карпенко, А. Рибченко та ін. У роботах згаданих авторів розглянуто окремі аспекти цифровізації системи дипломатичної служби України (безпекові, іміджеві, технічні, прогностичні).

Зовнішньополітичні цілі нашої держави, на реалізацію яких спрямовано інструментарій цифрової дипломатії, грунтовно проаналізовані в підручнику «Цифрова дипломатія» авторства Н. Піпченко, С. Макаренко та М. Рижкова. На сьогодні це одна з найбільш грунтовних праць в українському науковому середовищі, яка резюмує останні тенденції цифрової дипломатії (ЦД) країн світу (включно з українським досвідом) та комплексно окреслює державну політику України у сфері цифрової дипломатії.

Доцільно погодитися з авторами вищезгаданої книги, що цифрові технології суттєво впливають на традиційну дипломатію, змінюючи практику, пріоритети та характер діяльності зовнішньополітичних відомств. Вплив інформаційних технологій на дипломатію ХХІ століття настільки вагомий, що їх грунтовне вивчення та використання стало обов'язковим елементом фахової підготовки дипломатичних працівників. Цифрова дипломатія як невід’ємний елемент зовнішньої політики зарекомендувала себе ефективним інструментом позиціонування держави у світовому медіа-просторі, де потрібно рахуватися із щоразу більшою роллю недержавних акторів. Сучасна дипломатія передбачає розгалуженіше мережеве співробітництво, співпрацю в коаліціях та багатосторонніх групах, оскільки вирішення сучасних зовнішньополітичних завдань полягає здебільшого в досягненні балансу взаємовпливів міжнародних акторів.

Мета та завдання. Мета статті полягає у здійсненні порівняльного аналізу цифровізації дипломатичної практики України та Кувейту, виявленні спільних та відмінних характеристик цього процесу. Відповідно до поставленої мети окреслено такі завдання: 1) на основі аналізу наукової літератури 2019 - 2020 рр. стосовно досліджуваної проблематики з'ясувати цілі цифрової дипломатії України та Кувейту; 2) проаналізувати інструментарій цифрової дипломатії зазначених країн і його практичне застосування; 3) 3'ясувати виклики й тенденції розвитку цифрової дипломатії України та Кувейту; 4) укласти порівняльну таблицю для унаочнення спільних і відмінних рис у практиці ЦД України та Кувейту.

Методи дослідження. Досліджувана в цій статті проблематика та поставлені завдання зумовили використання декількох методів залежно від конкретних аспектів дослідження, зокрема методу контент-аналізу, порівняльного аналізу, синтезу та узагальнення.

Результати дослідження. Цифрова дипломатія як одна з найсучасніших форм дипломатичної діяльності стала беззаперечним трендом сьогодення, особливо в умовах пандемії Covid-19, яка наклала тимчасову заборону на традиційні форми дипломатичної практики країн світу. Вважаємо доцільним дослідити вплив інформаційно-комунікативних технологій (IКТ) на дипломатичну діяльність у всіх іiі виявах (консульська служба, публічна дипломатія, кризовий менеджмент), а також використання дипломатами IКТ з метою реалізації зовнішньополітичних цілей своїх країн. 
У наукових колах побутує думка, що рівень розвитку ЦД США, Великої Британії, Франції може слугувати передовим прикладом для таких країн, як Україна чи Кувейт, що лише розпочали розробляти відповідні стратегії ЦД. На сучасному етапі ЦД у США - це елемент влади (т. зв. «soft power»), що сприяє промоції національних інтересів США у світі. Велика Британія прагне зміцнити за рахунок ЦД свій позитивний імідж на міжнародній арені, пропагувати пріоритети своєї зовнішньої політики. Для Франції ЦД - це фактор посилення свого міжнародного впливу, інструмент іміджевої політики.

Водночас в Україні завдання ЦД мають певні особливості. На думку науковців Н. Піпченко, Є. Макаренко та М. Рижкова, потенціал ЦД у питанні захисту зовнішньополітичних інтересів нашої держави полягає в «реагуванні та запобіганні глобальним інформаційним загрозам...., зміцненні позицій держави у світовому інформаційному просторі, протидії поширенню в суспільній свідомості іноземних держав негативних уявлень про Україну» ${ }^{3}$.

В. Гуленко наголошує на необхідності створення підгрунтя для поширення важливих для України тез, зокрема політичних, за допомогою інструментів ЦД. Фахівець припускає, що довгострокова стратегія налагодження культурно-соціальної співпраці сприяла б формуванню сталих зв'язків між Україною та їі міжнародними партнерами. За правилами сучасної дипломатії спочатку необхідно донести свою думку до іноземної авдиторії, щоб згодом знайти партнерів в іноземному уряді ${ }^{4}$. У цьому контексті завдання дипломатів полягає в тому, щоб вивчити потенціал нових технологій і використати його для підвищення ефективності дипломатичної практики та досягнення зовнішньополітичних цілей.

Отже, ЦД України спрямована на забезпечення сталої інформаційної присутності у провідних медіа та цифровому просторі, що в довгостроковій перспективі має сприяти зміцненню міжнародного, інвестиційного, туристичного й культурного іміджу нашої держави.

Вважаємо доцільним погодитися з О. Русовою, що міждержавні комунікації в мережі «Інтернет» можуть вплинути на характер відносин і навіть актуальність досягнутих раніше домовленостей. Крім того, важливою є проблема кіберзагроз, які можуть розглядатися як посягання на державний суверенітет. Це $є$ фактором, що уможливлює відхід від театру дипломатичних дій у бік військових 5 .

Я. Матчук акцентує увагу на забезпеченні конфіденційності, цілісності, доступності та надійності інформації. Науковець також покликається на Закон України «Про основні засади забезпечення кібербезпеки України» від 2017 р., де «відображено цілісне розуміння безпеки в цифровому середовищі як поєднання технічної та соціально-гуманітарної складових частин інформаційної діяльності, тобто захисту контенту інформації та дотримання безпеки інфраструктури» ${ }^{6}$. Безпековий аспект ЦД $є$ надзвичайно актуальним для України в контексті конфлікту 3 Російською Федерацією та Кувейту через наявність джерел нестабільності в регіоні Близького Сходу.

3 огляду на високу технологічність інструментарію цифрової дипломатії, до ії цілей відносять налагодження миттєвої комунікації щодо проблемних питань, зберігання та оперування різного роду даними, підвищення ефективності інформаційно-роз'яснювальної роботи. Швидкість поширення інформації за допомогою ІКТ дуже висока. Що краще дипломати опановують ці технології, то ефективніше вони можуть контролювати порядок денний у цифровому середовищі.

Попри активне практичне використання Кувейтом засобів цифрової дипломатії, в електронних базах наукових публікацій («Google Scholar», «Academia Research», «JSTOR», «Digital Diplomacy Blog») наразі не опубліковано наукових статей на цю тему. Проте практичні аспекти цифрової дипломатії Кувейту наявні в низці державних програм і стратегій («Нові ідеї для Ку-

\footnotetext{
${ }^{3}$ Піпченко, Н., Макаренко, С., Рижков, М. (2019) Цифрова дипломатія. Підручник, ВАДЕКС, Київ. С. 286.

${ }^{4}$ Gulenko, V. (2020) 'Conventional Diplomacy Vs Digital Reality', UA: Ukraine Analytica 2(20), p. 16.

5 Rusova, O. (2020) 'Cyber Diplomacy: an Intangible Reality or a Fait Accompli?', UA: Ukraine Analytica 2(20), p. 26-33.

${ }^{6}$ Матчук, Я. (2019) «Безпековий аспект цифрової дипломатії», Міжнародні відносини Серія «Політичні науки»: матеріали конференції, № 21 (2019) [Онлайн]. URL: http://journals.iir.kiev.ua/index.php/ pol_n/article/view/3854/3514 (Accessed: 3 жовтня 2020 p.).
} 
вейту» ${ }^{7}$, «Нова візія Кувейту 2035» ${ }^{8}$ тощо). У цих програмах пропонується в середньостроковій перспективі реанімувати позиціонування Кувейту у світі, трансформувати Кувейт у регіональний (а згодом і міжнародний) фінансовий та торгівельний осередок, покращити інвестиційний клімат емірату.

Так, ЦД Кувейту, як і України, спрямована на забезпечення інформаційної присутності в міжнародному медіа-просторі, формування позитивного іміджу Кувейту в світі, проведення тематичних кампаній у соціальних мережах, а також модернізацію онлайн-сервісів для фізичних та юридичних осіб. Оскільки ЦД сприяє поширенню політичних цінностей та ідеологій, вона може слугувати потужним чинником промоції гуманітарних цінностей Кувейту, які становлять невід’ємну частину внутрішньої та зовнішньої політики цієї країни.

За допомогою інструментів публічної дипломатії Кувейт активно позиціонує себе як міжнародний гуманітарний донор. Така політика близькосхідного емірату є стратегічною, оскільки дозволяє уникати конфліктів з іншими країнами, обмежуючись роллю медіатора. На відміну від України, яка балансує між іміджем реципієнта та донора гуманітарної допомоги, Кувейт разом із Саудівською Аравією та ОАЕ, належать до провідних країн, які фінансують понад 90\% програм розвитку в арабських державах.

Серед отримувачів фінансової допомоги Кувейту передусім варто згадати Сирію, Ірак, Ємен, Палестину, африканські країни тощо. У серпні 2020 р. Кувейт надав Лівану 41 млн. дол. США для подолання наслідків вибуху в бейрутському порту. Кувейт фінансував також окремі гуманітарні проєкти в Україні. Зокрема, Кувейтський фонд арабського економічного розвитку надав на виконання проєкту «Укриття» в межах чорнобильської програми близько 15 млн дол. США.

Так, надання допомоги іншим країнам сприяло посиленню міжнародної репутації Кувейту. Уряд та недержавні благодійні організації емірату оперативно реагують на кризові гуманітарні ситуації в усіх країнах земної кулі ${ }^{9}$. Гуманітарна допомога стала візитівкою цієї країни на міжнародній арені. Підтвердженням цьому стало також надання покійному Еміру Кувейту С. А. Ас-Сабаху звання «Гуманітарний лідер» Генеральним секретарем ООН Пан Гі Муном у $2014 \mathrm{p}$.

Як і в Україні, забезпечення міжнародної безпеки та політика мирного вирішення конфліктів шляхом діалогу закріплена в головних принципах зовнішньої політики Кувейту. Вищезгадані досягнення емірату як частина дипломатичної практики активно поширювалися за допомогою засобів ІКТ та формували дискурс як зовнішньої, так і внутрішньої інформаційної політики.

У зв'язку з цим доцільно дослідити цифровий аспект публічної дипломатії Кувейту та України. На думку В. Гуленко, розуміння авдиторії, ії потреб та інтересів, дає можливість керувати нею і спрямовувати іiі у потрібне річище ${ }^{10}$. Схожа позиція простежується й у британського дослідника I. Манора, який вважає, що цифровізація публічної дипломатії відбувається у два етапи - на першому дипломати звертаються до цільової авдиторії, а на другому - коригують її ставлення до тих чи тих питань. Персоналізація новинних стрічок і реклами, підбір контенту в YouTube, Netflix з урахуванням зацікавлень людини, алгоритмізація процесів в соціальних мережах - усе це стає інструментами цифрового м'якого впливу.

Цифровізація дипломатії - це тривалий і поступовий процес, а не революційний стрибок. Відкриваючи нові можливості, технології водночас створюють і нові виклики, зокрема, у царині щоденних дипломатичних завдань ${ }^{11}$. Нині у світі спостерігається активна цифровізація окремих аспектів поточної роботи дипломатів.

Термінологічний словник сучасного дипломата містить такі поняття, як дипломатичний вебменеджмент, посольство даних, віртуальний посол, віртуальне посольство тощо, які стали

\footnotetext{
${ }^{7}$ Al-Salim, A. (2020) 'New ideas for Kuwait', Kuwait: Kuwaitimpakt, p. 24-25.

${ }^{8}$ Ministry of Foreign Affairs of Kuwait (2017) Kuwait Vision 2035 'New Kuwait' [Online]. Available at: https://www.mofa.gov.kw/en/kuwait-state/kuwait-vision-2035/ (Accessed: 6 October 2020).

${ }^{9}$ Leichtman, M. A. (2017) 'Kuwaiti Humanitarianism: The History and Expansion of Kuwait's Foreign Assistance Policies' [Online]. Available at: https://www.stimson.org/wp-content/files/fileattachments/Kuwaiti\% 20Humanitarianism-\%20The\%20History\%20and\%20Expansion\%20of\%20Kuwaits\%20Foreign \%20Assistance \%20Policies_0.pdf (Accessed: 3 October 2020).

${ }^{10}$ Gulenko, V. (2020) Op. cit., p. 15.

${ }^{11}$ Manor, I. (2019) The Digitalization of Public Diplomacy. Oxford: Palgrave Macmillan, p. 66.
} 
реаліями дипломатичних буднів. Безперечно, інноваційний та креативний підхід до виконання службових обов'язків прямо пропорційний ефективності виконуваної роботи.

Так, дипломати ФРН записують подкасти з питань, що входять у сферу їхньої компетенції та поширюються на відомих інтернет-платформах (SoundCloud, iTunes тощо). Організація «DiploFoundation», заснована у 2002 р. за підтримки урядів Мальти та Швейцарії, створює «ЕDiplomacy cartoons» - комікси про роботу дипломатів в епоху цифровізації дипломатичної практики. ЦД Святого Престолу почала застосовувати найсучасніші IКТ для пропагування цінностей християнства. Зокрема, у 2019 р. Ватикан презентував електронні чотки для молитов «eRosary». Прилад працює в парі зі спеціальним мобільним додатком, який активується при проведенні поблизу екрану смартфона «розумним хрестом», що є частиною чоток-браслету ${ }^{12}$.

Останніми роками арсенал цифрових інструментів кувейтських та українських органів виконавчої влади, зокрема МЗС, також збагатився великою кількістю цифрових нововведень. Інструментарій ЦД нині є потужним елементом зовнішньої політики, спрямованим на нейтралізацію негативних уявлень про державу, промоцію іiї різностороннього потенціалу та зміцнення позицій у світі.

Н. Піпченко, Є. Макаренко, М. Рижков, І. Манор відзначають стрімкий злет застосування цифрової дипломатії МЗС України після конфлікту у 2014 р. Насамперед це виявилося у зростанні кількості читачів сторінок МЗС та українських дипломатичних установ за кордоном у соціальних мережах та посиленні цифрової діяльності дипломатів. Спалах пандемії Covid-19 лише надав нового імпульсу зазначеним процесам, коли Інтернет став чи не єдиною платформою дипломатичної діяльності як для України, так і для Кувейту. Можливо, зарано говорити про повний перехід дипломатії в цифровий вимір, проте дипломатія цифровізується дедалі більше.

Багато аспектів української дипломатії зазнали вдосконалення завдяки IKT, посилено інституційні засади ії розвитку. Постановою КМУ №849 від 29.09.2019 р. було затверджено Програму діяльності Кабінету Міністрів України, для виконання якої Міністерство цифрової трансформації України запровадило національну онлайн-платформу з цифрової грамотності «Дія. Цифрова освіта» ${ }^{13}$.

В Україні вагомим кроком у поширенні цифрової дипломатії є створення Українського інституту. Інструментами міжнародних комунікацій цієї державної установи є масштабні інформаційні онлайн-кампанії та спільні спецпроєкти з іноземними ЗМІ та Українським культурним фондом. У липні 2020 р. Кабінет міністрів України призначив Заступника Міністра закордонних справ 3 питань цифрового розвитку, цифрових трансформацій та цифровізації, у коло обов'язків якого входять питання оцифровування внутрішніх процесів МЗС та послуг, які Міністерство надає громадянам і юридичним особам. Штатним розписом апарату Міністерства також передбачений Департамент комунікацій та публічної дипломатії ${ }^{14}$. На відміну від України, ЦД у Кувейті не зазнала схожого інституційного розвитку.

У 2020 р. процеси цифровізації консульської служби України засвідчили суттєвий прогрес. На консульському напрямку в межах організації прийому громадян запроваджено механізм електронної черги ${ }^{15}$. Завдяки спеціальній онлайн-формі на сайті МЗС України відвідувачі консульських підрозділів українських дипломатичних установ за кордоном відтепер мають змогу попередньо реєструватися в режимі онлайн, обирати дату і час візиту до консульського підрозділу та оперативно дізнаватися перелік необхідних документів для здійснення обраного виду консульської послуги.

У Кувейті, як і в Україні, у межах цифровізації консульських послуг у липні 2020 р. реалізовано електронну чергу для відвідувачів Консульського підрозділу сертифікації. Електронний сервіс доступний також на іншій державній платформі «Уряд Кувейту онлайн», що пропонує широкий спектр онлайн-послуг для громадян Кувейту (30\% від загальної кількості населення

\footnotetext{
12 Піпченко, Н., Макаренко, Є., Рижков, М. (2019) Вказ. пр., с. 157-240.

${ }^{13}$ Постанова Верховної Ради України (2019) Програма діяльності Кабінету Міністрів України [Онлайн]. URL: https://zakon.rada.gov.ua/laws/show/849-2019-п\#Text (10 жовтня 2020 p.).

14 Міністерство закордонних справ України (2020) Структура. Керівництво [Онлайн]. URL: https://mfa.gov.ua/ pro-ministerstvo/struktura (5 жовтня 2020 p.).

15 Там само.
} 
емірату) та іноземців (70\% населення) щодо стану готовності окремих видів документів, віз, наявності порушень тощо.

У контексті захисту українських громадян варто зазначити, що навесні 2020 р. у зв'язку зі спалахом пандемії Covid-19 на сторінках українських посольств в мережі «Фейсбук» були створені групи під уніфікованою назвою «Захист українців». У цих групах співробітники закордонних дипломатичних установ України допомагали координувати допомогу й підтримку громадян України, які опинилися в іноземних країнах у період обмеження регулярного міжнародного транспортного сполучення. Створені раніше онлайн-платформи «Друг», «Поради подорожуючим», «е-Консул» та ін. покликані спростити надання оперативної підтримки та сприяння українським громадянам за кордоном, зокрема, у випадку надзвичайних подій, а також сформувати позитивне ставлення до роботи консулів. На відміну від України, МЗС Кувейту поки що не має аналогів таких онлайн-платформ.

Крім того, спостерігається також иифрова трансформація повсякденної роботи працівників дипломатичної служби України та Кувейту. Цифрова комунікація як одна з ключових «м'яких навичок» урізноманітнилася завдяки сучасним засобам IКТ. Так, додатки Google (Google Docs, Google Sheets, Google Drive та ін.) та інші хмарні сервіси слугують інструментами для налагодження швидкого та ефективного спілкування між дипломатами в різних куточках світу.

Масштабне оновлення торкнулося й офіційного сайту МЗС України, який включає посилання на понад 100 сайтів українських закордонних представництв. За результатами впровадження нового дизайну сайти українських посольств за кордоном отримали інтуїтивно зрозумілий інтерфейс, адаптований до мобільних пристроїв, дружній чат-бот, а також технічну можливість підтримки 32 мов світу. На сайті МЗС України наявна інформаційна стрічка 3 новинами, сторінка-каталог з посольствами іноземних держав в Україні та інші корисні функції, що стали візитівкою оновленої концепції сайту зовнішньополітичного відомства України ${ }^{16}$.

Вебсайт МЗС Кувейту, що підтримується арабською та англійською мовами, поділений на 5 логічних блоків (інформація про керівництво, структуру МЗС та дипломатичні установи Кувейту за кордоном, медіа-центр, стратегія зовнішньої політики Кувейту, дорожня карта розвитку Кувейту до 2035 р., а також форма для зворотного зв'язку). Чітка горизонтальна структура сайту не передбачає стрічки новин, календаря подій чи оновлень щодо пандемії Covid-19.

Повертаючись до питання функціонування офіційних акаунтів дипломатичних установ України в соціальних мережах, варто зазначити, що в 2020 р. переважну більшість сторінок було верифіковано. Відповідний синій бейдж біля назви сторінки свідчить про достовірність акаунта того чи того посольства та допомагає убезпечити користувачів соціальних мереж від фейкових повідомлень, які поширюють зловмисники з підроблених сторінок.

Значно розширився набір інструментів ЦД. У період дії карантинних обмежень у зв'язку зі спалахом Covid-19 українські дипломати за кордоном переглянули план публічних заходів, переформовувавши більшість 3 них у вебінари, відео-конференції, інформаційні онлайн-кампанії та медіа-марафони. Навіть мистецькі події (художні виставки та музичні концерти) перенесли у віртуальні тривимірні галереї та концертні зали.

У липні 2020 р. спільно з Міністерством закордонних справ України Український інститут провів «серію дискусій про культурну дипломатію України» ${ }^{17}$. У відкритому обговоренні, яке транслювалося в режимі онлайн у соціальних мережах, фахові експерти дискутували на тему історії розвитку культурної дипломатії в Україні та перспектив ії подальшого розвитку в контексті регіональних пріоритетів. Обговорювалися питання синергії гравців у сфері реалізації культурної дипломатії України, інструментарій публічної дипломатії тощо. Український інститут презентував 5-річну середньострокову стратегію діяльності на 2020-2024 рр., визначивши свою місію як: «зміцнення міжнародної і внутрішньої суб'єктності України через можливості культурної дипломатії» ${ }^{18}$.

16 Kitsoft. IT для держави та бізнесу (2020) Проєкт «Вебпортал Міністерства закордонних справ Украӥни» [Онлайн]. URL: https://www.kitsoft.kiev.ua/portfolio-item/portal-ministerstvo-zakordonnyh-spravukrayiny/ (4 жовтня 2020 p.).

17 Синергія гравців у сфері реалізації культурної дипломатії України (2020) Український інститут [Онлайн]. URL: https://www.facebook.com/watch/live/?v=618239732154445\&ref=watch_permalink (12 жовтня 2020 p.).

${ }^{18}$ Шейко, В., Філевська, Т. (2020) Стратегія Українського інституту на 2020-2024 роки. Київ, с. 21. 
Питання цифровізації державної служби Кувейту та їі дипломатичного складника досліджувалися в межах конференцій та тематичних форумів: «Цифрові зв'язки з громадськістю та цифрова дипломатія», «Цифрова дипломатія в еру дезінформації», «Цифрова трансформація Кувейту» тощо. Під час таких заходів експерти в галузі цифрових технологій пропонували офіційним та діловим колам Кувейту не лише технічні рішення нагальних проблем, але й стратегії подальшої цифровізації, засновані на успішних кейсах інших держав.

Зокрема, у Кувейті досліджуються перспективи застосування хмарних сервісів, великих даних (big-data), інтернету речей, машинного навчання, технологій блокчейну та робототехніки. Популярною платформою для науковців та практиків у цій сфері стала щорічна конференція «e-Government Forum», що проводиться під егідою Прем'єр-міністра Кувейту з 2012 р., - захід, присвячений обговоренню сучасних трендів смартдержави (розумної держави). Кувейт має на меті таким чином долучитися до міжнародної цифрової спільноти, пришвидшити цифрову трансформацію державних процесів за прикладом сусідніх країн, запровадити цифрові послуги для резидентів та громадян емірату.

Порівняно з Кувейтом, в Україні ичифровізація професійного навчання працівників дипломатичної служби відбувається швидше. Дипломатична академія України імені Геннадія Удовенка при МЗС започаткувала у 2019 р. освітню інтернет-платформу «Академія Онлайн», що містить лекції, презентації, тематичні курси, текстові матеріали, навчальні посібники й електронну бібліотеку. За час карантину авдиторія «Академії Онлайн» зросла в 5 разів та була доповнена новими курсами, презентаціями та лекціями. Наразі освітня платформа містить матеріали 28 лекцій англійською та/або українською мовами з публічної дипломатії, енергетичної безпеки, ситуаційного аналізу, комунікації, риторики, організації та супроводу протокольних заходів, міжнародного кримінального судочинства, цифрової дипломатії, питань газової сфери, Свропейської інтеграції в контексті світових глобалізаційних процесів тощо ${ }^{19}$. Крім того, МЗС активно впроваджує практику онлайн-тренінгів, дискусій, вебінарів та презентацій для українських дипломатів за кордоном за участі провідних галузевих спеціалістів.

Переходячи до огляду цифрового дипломатичного інструментарію Кувейту, варто зазначити брак відкритих наукових джерел (англійсько- чи арабськомовних), які дозволяють здійснити розширений аналіз практики цифрової дипломатії цієї країни. Щоб скласти уявлення про стан розвитку цифрової дипломатії Кувейту, доцільно покладатися на безпосередню фіксацію онлайн-активності МЗС емірату на офіційному вебсайті та в соціальних мережах. Для цього дослідження залучено також інформаційні повідомлення про застосування IКТ в системі державної служби емірату, а ключовим джерелом інформації слугували вебсайт МЗС Кувейту та його офіційні акаунти у твіттері, інстаграмі, фейсбуці.

Прикметно, що на 4.24 млн повністю урбанізованого населення Кувейту припадає 7.38 млн активних мобільних телефонів (174\% від загальної кількості населення емірату). Так, 99\% від загальної кількості населення є активними користувачами інтернету та соціальних мереж. 3 2019 р. активність населення Кувейту в соціальних мережах підвищилася на $3.8 \%$. Майже $100 \%$ користувачів найпопулярніших соціальних мереж (переважно «Твіттер» та «Інстаграм») використовують для спілкування смартфони ${ }^{20}$.

Створена у липні 2009 р., твіттер-сторінка МЗС Кувейту нараховує близько 230 тис. читачів (для порівняння, офіційна твіттер-сторінка МЗС України, яка створена у 2010 р., має лише 94 тис. читачів). Попри те, що контент цієї сторінки майже повністю дублюється на платформах «Фейсбук» та «Інстаграм», твіттер користується абсолютною популярністю в кувейтському суспільстві, що зумовлює гарні показники залученості аудиторії ${ }^{21}$. Доцільно зазначити, що інстаграм-сторінка МЗС Кувейту налічує 43 тис. читачів, що майже в 10 разів перевищує кількість читачів сторінки МЗС України на цій платформі.

Натомість, створена у грудні 2010 р. фейсбук-сторінка МЗС Кувейту нараховує лише близько 15 тис. читачів (для порівняння, фейсбук-сторінка МЗС України має 70 тис. читачів). Як і

\footnotetext{
19 Дипломатична академія України імені Геннадія Удовенка при МЗС (2020) «Академія Онлайн» [Онлайн]. URL: http://da.mfa.gov.ua/news/rozshyrennya-mozhlyvostej-osvitnoyi-platformy-dystantsijnoyi-osvityakademiya-onlajn-otrymannya-sertyfikatu-pislya-pidsumkovogo-testuvannya/ (10 жовтня 2020 p.).

${ }^{20}$ Datareportal (2020) Digital 2020: Kuwait [Online]. Available at: https://datareportal.com/reports/digital-2020kuwait [Accessed: 9 October 2020].

${ }^{21}$ Ibid.
} 
інші онлайн-сторінки МЗС Кувейту, фейсбук використовується переважно для трансляції ключових тез Голови зовнішньополітичного відомства країни, важливих заяв і коментарів пресцентру Міністерства. Переважну більшість контенту сторінки становлять тезові повідомлення арабською мовою про зустрічі й візити Міністра, його заступника, а також Послів Кувейту за кордоном. Стиль офіційної сторінки МЗС Кувейту є досить витриманим та однотипним. Імовірно, що емоційна нейтральність та одномовний канал комунікації текстових повідомлень зумовлюють невелику залученість аудиторії. В середньому дописи в мережі «Фейсбук» отримують до 20 вподобань, і тільки найбільш резонансні публікації поширюють читачі. Вочевидь, однією з основних цільових авдиторій фейсбук-сторінки МЗС Кувейту є громадяни емірату та місцеві журналістські кола.

Для унаочнення спільних і відмінних рис у практиці ЦД України та Кувейту вважаємо доцільним навести їх у авторській порівняльній таблиці (1).

Табличя 1.

Порівняльна характеристика цифрової дипломатії України та Кувейту.

\begin{tabular}{|c|c|c|}
\hline & Україна & Кувейт \\
\hline Завдання ЦД & $\begin{array}{l}\bullet \text { Належне } \\
\text { України у свізиціонування } \\
\text { донесення важливих політичних тез до } \\
\text { міжнародної спільноти; } \\
\text { • нейтралізація негативних уяв- } \\
\text { лень про Україну; } \\
\text { • реагування та запобігання ін- } \\
\text { формаційним загрозам, дез-інформації; } \\
\text { • покращення кризових ко- } \\
\text { мунікацій та та інформаційно- } \\
\text { роз'яснювальної роботи. }\end{array}$ & $\begin{array}{l}\bullet \text { Формування позитивного } \\
\text { іміджу Кувейту у світі; } \\
\bullet \quad \text { поширення політичних та } \\
\text { гуманітарних цінностей Кувейту } \\
\text { за кордоном; } \\
\text { • поліпшення якості кон- } \\
\text { сульських та інших онлайн- } \\
\text { послуг. }\end{array}$ \\
\hline $\begin{array}{c}\text { Механізми ре- } \\
\text { алізації ЦД }\end{array}$ & $\begin{array}{l}\bullet \text { Вебсайт МЗС, акаунти МЗС у } \\
\text { мережах «Фейсбук», «Твіттер», «Інста- } \\
\text { грам»; } \\
\bullet \quad \text { інформаційні онлайн-кампанії } \\
\text { та спецпроєкти } 3 \text { іноземними 3МІ, } \\
\text { цифрові заходи публічної дипломатії; } \\
\bullet \quad \text { оцифрування внутрішніх про- } \\
\text { цесів МЗС та послуг; } \\
\text { • цифрові продукти у сфері кон- } \\
\text { сульського обслуговування (онлайн- } \\
\text { платформи, електронна черга тощо). }\end{array}$ & $\begin{array}{l}\bullet \text { Вебсайт МЗС, акаунти } \\
\text { МЗС у мережах «Твіттер», «Ін- } \\
\text { стаграм», «Фейсбук»; } \\
\text { • цифрові інструменти кон- } \\
\text { сульського спрямування. }\end{array}$ \\
\hline $\begin{array}{l}\text { Досягнення i } \\
\text { виклики ЦД }\end{array}$ & $\begin{array}{l}\bullet \text { Вдалося розпочати інсти- } \\
\text { туалізацію державної практики ЦД і } \\
\text { фахову підготовку дипломатів у сфері } \\
\text { ЦД, збагатити інструментарій ЦД. } \\
\bullet \quad \text { Невирішеними залишаються } \\
\text { питання фінансового та кадрового за- } \\
\text { безпечення ЦД, розроблення стратегії } \\
\text { використання ІКТ у повсякденній ро- } \\
\text { боті дипломата. }\end{array}$ & $\begin{array}{l}\text { • Вдалося налагодити } \\
\text { адміністрування офіційних циф- } \\
\text { рових платформ ЦД, збагатити } \\
\text { інструментарій Цд. } \\
\text { • Невирішеними залиша- } \\
\text { ються питання налагодження ін- } \\
\text { терактивності та зворотного } \\
\text { зв'язку, забезпечення візуалізації } \\
\text { поширюваної інформації, ак- } \\
\text { тивізації функціонування веб- } \\
\text { сайтів і соціальних мереж МЗС, } \\
\text { запровадження багатомовного } \\
\text { мовлення. }\end{array}$ \\
\hline $\begin{array}{c}\text { Особливості } \\
\text { розвитку ЦД }\end{array}$ & $\begin{array}{l}\text { • Початок зовнішньої військової } \\
\text { агресії у } 2014 \text { р. став одним із каталіза- } \\
\text { торів стрімкого розвитку ЦД в Україні. }\end{array}$ & $\begin{array}{l}\text { • Події «Арабської весни» } \\
\text { посилили увагу до інструментів } \\
\text { ЦД. Нині вивчаються можливості }\end{array}$ \\
\hline
\end{tabular}




• У зв'язку з Covid-19 активно
здійснюється цифровізація про-
фесійного навчання працівників ди-
пломатичної служби (зокрема, в ча-
стині цифрової освіти).

- У зв'язку з Covid-19 активно фесійного навчання працівників дистині цифрової освіти). застосування в межах ЦД хмарних сервісів, великих даних (bigdata), інтернету речей, машинного навчання, технологій блокчейну та робототехніки.

Підсумовуючи вищезазначену інформацію щодо сучасного стану розвитку цифрової дипломатії України та Кувейту, можемо констатувати значне збагачення ії інструментарію. Водночас ця сфера не позбавлена проблемних питань, зокрема: складність налагодження інтерактивності та зворотного зв'язку від дипломатів в соціальних мережах, підвищення рівня візуалізації поширюваної інформації, розроблення стратегії використання ІКТ в поточній роботі дипломата, спрямування можливостей ЦД для вдосконалення внутрішньої комунікації та координації в системі МЗС, надання більшої уваги функціонуванню вебсайтів дипломатичних установ.

В Україні констатується недостатня практичність чинних державних програм, які мали б регулювати програмно-інституціональне забезпечення ЦД України. Імовірно, що більшість проблем ЦД України не вирішуються через брак коштів та кадрового забезпечення.

Натомість у Кувейті не спостерігається нестача бюджетних коштів на цифрову трансформацію процесів державного управління, зокрема, із залученням технологій штучного інтелекту. Згідно з національним планом «Візія смартміста», до 2035 р. робота всіх державних органів й установ Кувейту має цифровізуватися ${ }^{22}$. Такий підхід дещо співзвучний з концепцією «держави в смартфоні», яка запроваджується в Україні з метою спрощення надання державних послуг та підвищення рівня їхньої прозорості.

Кувейтські експерти, зокрема, Саад Аль-Алі (Заступник Генерального директора кувейтського новинного агентства KUNA) та Саад Абдулла Ар-Рубаян (Радник з питань зв'язків з громадськістю та урядової комунікації) наголошують на необхідності активнішого використання інструментарію цифрової дипломатії для зміцнення позитивного іміджу Кувейту на міжнародній арені.

С. Ар-Рубаян підкреслює важливість урізноманітнення медійної діяльності департаменту публічної дипломатії МЗС Кувейту за рахунок упровадження інфографіки, аудіовізуального контенту, багатомовного мовлення. На думку експерта, ключові тези переговорів кувейтських делегацій та укладених Кувейтом міжнародних договорів подекуди складно помітити серед беззмістовних статей та дописів у соціальних мережах, адже протокольні повідомлення офіційних кіл емірату не завжди розкривають сутність державних кроків у сфері зовнішньої політики.

На думку С. Ар-Рубаяна, професійне та якісне адміністрування вебсайтів і соціальних мереж МЗС Кувейту та його дипломатичних місій за кордоном сприятиме ліпшому донесенню офіційної позиції Кувейту до його громадян та міжнародної спільноти. У цьому контексті С. Ар-Рубайан ставить у приклад Еміра Дубаю, Прем'єр-міністра і Віце-президента ОАЕ Шейха Мохаммеда бін Рашида Аль Мактума, який активно веде соціальні мережі, підтримуючи тим самим інформаційну присутність ОАЕ в міжнародному просторі ${ }^{23}$. Одним із головних викликів сучасної цифрової дипломатії Кувейту залишається невикористаний потенціал інструментарію соціальних мереж та графічного дизайну.

Кувейтські дипломати (зокрема Посол Дж. Аль-Будайві) відзначають, що зростання уваги близькосхідних країн до соціальних мереж та їх стрімке впровадження в дипломатичну практику відбулося переважно після подій «Арабської весни» 2011 р. Як і в Україні у 2014 р., у результаті таких процесів у Кувейті значно збільшилася кількість користувачів соціальних мереж. Нині соціальні мережі в Кувейті слугують також для моніторингу думок та настроїв у суспільстві з міркувань безпеки і для упередження дезінформації. Утім, потенціал соціальних мереж значно ширший та може певною мірою впливати на формування думок та поглядів цільової авдиторії, як стверджують І. Манор, К. Бьйола та інші науковці.

\footnotetext{
${ }^{22}$ The European Business Review (2020) 'Kuwait Keen on Digital Transformation to Build a Society Based on Smart E-services' [Online]. Available at: https://www.europeanbusinessreview.com/kuwait-keen-on-digitaltransformation-to-build-a-society-based-on-smart-e-services/ (Accessed: 3 October 2020).

${ }^{23}$ Alrubaiaan, S. (2018) 'Digital Diplomacy of Kuwait' [Online]. Available at: https://alqabas.com/article/ 564570-الدبلوماسية_الكويتية_الرقمية'Accessed: 8 October 2020).
} 
Ураховуючи те, що потенціал цифрової дипломатії дозволяє вирішити комплекс проблем (від налагодження комунікації між урядовими відомствами до протидії інформаційним загрозам), скоординована та всеохопна імплементація цього інструменту в дипломатичну практику має дуже високу актуальність.

Висновки. У результаті дослідження наукових публікацій та аналізу практики цифрової дипломатії України та Кувейту з'ясовано, що в обох країнах увага до ЦД різко зросла після резонансних подій, а саме: в Україні від початку російської агресії у 2014 р., у Кувейті після подій «Арабської весни» у 2011 р.

Цілі ЦД обох країн є дуже близькими: зміцнення позицій держави у світовому інформаційному просторі, поліпшення якості електронних послуг (зокрема консульських), запобігання інформаційним загрозам, а також промоція національних цінностей у світі. Водночас в Україні особлива увага приділяється цифровій трансформації поточної роботи дипломата в межах внутрішньовідомчих комунікацій та виконання дипломатичних завдань. Про це свідчить запровадження системної цифрової освіти для українських дипломатів, розроблення відповідних тематичних тренінгів, методичних посібників і семінарів. У Кувейті також спостерігається тенденція до цифрової трансформації дипломатичної роботи та сфери державних послуг у цілому. ІКТ в дипломатичній практиці Кувейту застосовуються здебільшого для оптимізації часу та ресурсів на виконання дипломатичних завдань.

Зважаючи на вищенаведене, доцільно зазначити, що суть цифрової дипломатії полягає в застосуванні ІКТ для здійснення дипломатичних функцій та вирішення професійних завдань дипломатів. Натомість цифровізація (цифрова трансформація) - це всеохопна інтеграція цифрових технологій у різні сфери діяльності людини.

Установлено, що активне застосування широкого інструментарію цифрової дипломатії сприяє підвищенню ефективності дипломатичної служби в досягненні зовнішньополітичних цілей. Відповідно у практиці ЦД України та Кувейту переважають такі інструменти, як соціальні мережі (інтерактивна платформа для інформаційних кампаній, медіа-марафонів, спецпроєктів зі ЗМІ, моніторингу та коригування суспільної думки), вебсайти міністерств закордонних справ (платформа для поширення офіційних позицій держави, депозитарій ключової інформації в межах компетенції зовнішньополітичного відомства) та програмні продукти для надання послуг консульського характеру. Характерною рисою цифрової дипломатії України $\epsilon$ цифрові освітні та культурно-мистецькі майданчики (медіа-платформи), тимчасом як у Кувейті більш розповсюджені механізми твіттер-дипломатії.

До ключових викликів цифрової дипломатії України та Кувейту належать: розроблення стратегії розвитку цифрової дипломатії, підвищення рівня візуалізації поширюваної інформації, забезпечення інтерактивності та комунікації в соціальних мережах з громадянами, а також запобігання кіберзагрозам і дезінформації в цифровому просторі.

3 огляду на загострення епідеміологічної ситуації у світі внаслідок поширення Covid-19, актуальність цифрової дипломатії лише зростатиме. Отже, подальше дослідження застосування цифрових інновацій (штучний інтелект, чат-боти, великі дані тощо) у дипломатичній практиці може стати перспективною темою для подальших досліджень.

\section{Список джерел}

1. Дипломатична академія України імені Геннадія Удовенка при МЗС (2020) Академія Онлайн [Онлайн]. URL: http://da.mfa.gov.ua/news/rozshyrennya-mozhlyvostej-osvitnoyi-platformydystantsijnoyi-osvity-akademiya-onlajn-otrymannya-sertyfikatu-pislya-pidsumkovogo-testuvannya/ (Accessed: 10 жовтня 2020 р.).

2. Матчук, Я. (2019) «Безпековий аспект цифрової дипломатії», Міжнародні відносини Серія «Політичні науки»: матеріали конференціï, № 21 (2019) [Онлайн]. URL: http://journals.iir.kiev.ua/index.php/pol_n/article/view/3854/3514 (Accessed: 3 жовтня 2020 p.).

3. Міністерство закордонних справ України (2020) Структура. Керівництво [Онлайн]. URL: https://mfa.gov.ua/pro-ministerstvo/struktura (Accessed: 5 жовтня 2020 p.).

4. Піпченко, Н., Макаренко, С., Рижков, М. (2019) Цифрова дипломатія. Підручник, ВАДЕКС, Київ, 318 с. 
5. Постанова Верховної Ради України (2019) Програма діяльності Кабінету Міністрів України [Онлайн]. URL: https://zakon.rada.gov.ua/laws/show/849-2019-n\#Text (Accessed: 10 жовтня 2020 р.).

6. Синергія гравців у сфері реалізації культурної дипломатії України (2020) Український інститут [Онлайн]. URL: https://www.facebook.com/watch/live/?v=618239732154445\&ref= watch_permalink (Accessed: 12 жовтня 2020 p.).

7. Шейко, В., Філевська, Т. (2020) Стратегія Украӥнського інституту на 2020-2024 роки. Київ, 50 с.

8. Kitsoft. IT для держави та бізнесу (2020) Проєкт «Вебпортал Міністерства закордонних справ України» [Онлайн]. URL: https://www.kitsoft.kiev.ua/portfolio-item/portal-ministerstvozakordonnyh-sprav-ukrayiny/ (Accessed: 4 жовтня 2020 p.).

9. Al-Salim, A. (2020) 'New ideas for Kuwait', Kuwait: Kuwaitimpakt, 26 p.

10. Alrubaiaan, S. (2018) 'Digital Diplomacy of Kuwait' [Online]. Available at: https://alqabas.com/article/564570-الدبلوماسية_الكويتية_الرقمية' (Accessed: 8 October 2020).

11. Datareportal (2020) Digital 2020: Kuwait [Online]. Available at: https://datareportal.com/reports/digital-2020-kuwait (Accessed: 9 October 2020).

12. Gulenko, V. (2020) 'Conventional Diplomacy Vs Digital Reality', UA: Ukraine Analytica, 2(20), p. 11-18.

13. Leichtman, M. A. (2017) 'Kuwaiti Humanitarianism: The History and Expansion of Kuwait's Foreign Assistance Policies' [Online]. Available at: https://www.stimson.org/wp-content/files/file attachments/Kuwaiti\%20Humanitarianism-\%20The\%20History\%20and\%20Expansion\%20of\%20

Kuwaits\%20Foreign\%20Assistance\%20Policies_0.pdf (Accessed: 3 October 2020).

14. Manor, I. (2019) The Digitalization of Public Diplomacy, Palgrave Macmillan, Oxford, 356 p.

15. Ministry of Foreign Affairs of Kuwait (2017) Kuwait Vision 2035 'New Kuwait' [Online]. Available at: https://www.mofa.gov.kw/en/kuwait-state/kuwait-vision-2035/ (Accessed: 6 October 2020).

16. Rusova, O. (2020) 'Cyber Diplomacy: an Intangible Reality or a Fait Accompli?', UA: Ukraine Analytica 2(20), p. 26-33.

17. The European Business Review (2020) 'Kuwait Keen on Digital Transformation to Build a Society Based on Smart E-services' [Online]. Available at: https://www.europeanbusinessreview. com/kuwait-keen-on-digital-transformation-to-build-a-society-based-on-smart-e-services/ (Accessed: 3 October 2020).

\section{References}

1. Dyplomatychna akademiia Ukrainy imeni Hennadiia Udovenka pry MZS (2020) Akademiya Onlain [Online]. Available at: http://da.mfa.gov.ua/news/rozshyrennya-mozhlyvostej-osvitnoyiplatformy-dystantsijnoyi-osvity-akademiya-onlajn-otrymannya-sertyfikatu-pislya-pidsumkovogotestuvannya/ (Accessed: 10 October 2020).

2. Matchuk, Ya. (2019) 'Bezpekovyj aspekt tsyfrovoi dyplomatii', Mizhnarodni vidnosyny Seriia 'Politychni nauky': materialy konferentsii № 21 (2019) [Online]. Available at: http://journals.iir.kiev.ua/index.php/pol_n/article/view/3854/3514 (Accessed: 3 October 2020).

3. Ministerstvo zakordonnyh sprav Ukrainy (2020) Struktura. Kerivnytstvo [Online]. Available at: https://mfa.gov.ua/pro-ministerstvo/struktura (Accessed: 5 October 2020).

4. Pipchenko, N., Makarenko, Ye., Ryzhkov, M. (2019) Tsyfrova dyplomatia. Pidruchnyk, VADEX, Kyiv, $318 \mathrm{c}$.

5. Postanova Verhovnoi Rady Ukrainy (2019) Prohrama diialnosti Kabinetu Ministriv Ukrainy [Online]. Available at: https://zakon.rada.gov.ua/laws/show/849-2019-n\#Text (Accessed: 10 October 2020).

6. Synerhiia hravtsiv u sferi realizatsii kulturnoi dyplomatii Ukrainy (2020) Ukraiinskyi Institut [Online]. Available at: https://www.facebook.com/watch/live/?v=618239732154445\&ref= watch_permalink (Accessed: 12 October 2020).

7. Sheiko, V., Filevska, T. (2020) Stratehia Ukrainskoho instytutu na 2020-2024 roky. Kyiv, 50 p. 
8. Kitsoft. IT dlya derzhavy ta biznesu (2020) Proyekt «Vebportal Ministerstva zakordonnyh sprav Ukrainy» [Online]. Available at: https://www.kitsoft.kiev.ua/portfolio-item/portal-ministerstvozakordonnyh-sprav-ukrayiny/ (Accessed: 4 October 2020).

9. Al-Salim, A. (2020) 'New ideas for Kuwait', Kuwait: Kuwaitimpakt, 26 p.

10. Alrubaiaan, S. (2018) 'Digital Diplomacy of Kuwait' [Online]. Available at: https://alqabas.com/article/564570-الدبلوماسية_الكويتية_الرقمية، (Accessed: 8 October 2020).

11. Datareportal (2020) Digital 2020: Kuwait [Online]. Available at: https://datareportal.com/reports/digital-2020-kuwait (Accessed: 9 October 2020).

12. Gulenko, V. (2020) 'Conventional Diplomacy Vs Digital Reality', UA: Ukraine Analytica 2(20), p. 11-18.

13. Leichtman, M. A. (2017) 'Kuwaiti Humanitarianism: The History and Expansion of Kuwait's Foreign Assistance Policies' [Online]. Available at: https://www.stimson.org/wp-content/files/file attachments/Kuwaiti\%20Humanitarianism-\%20The\%20History\%20and\%20Expansion\%20of\%20 Kuwaits\%20Foreign\%20Assistance\%20Policies_0.pdf (Accessed: 3 October 2020).

14. Manor, I. (2019) The Digitalization of Public Diplomacy, Palgrave Macmillan, Oxford, 356 p.

15. Ministry of Foreign Affairs of Kuwait (2017) Kuwait Vision 2035 'New Kuwait' [Online]. Available at: https://www.mofa.gov.kw/en/kuwait-state/kuwait-vision-2035/ (Accessed: 6 October 2020).

16. Rusova, O. (2020) 'Cyber Diplomacy: an Intangible Reality or a Fait Accompli?', UA: Ukraine Analytica 2(20), p. 26-33

17. The European Business Review (2020) 'Kuwait Keen on Digital Transformation to Build a Society Based on Smart E-services' [Online]. Available at: https://www.europeanbusinessreview. com/kuwait-keen-on-digital-transformation-to-build-a-society-based-on-smart-e-services/ (Accessed: 3 October 2020). 